\title{
Cysteinyl-leukotriene $_{1}$ receptor antagonist prevents urological cancer cell growth through early apoptosis
}

\author{
MASAHIDE MATSUYAMA ${ }^{1}$, KIYOAKI FUNAO ${ }^{1}$, KATSUYUKI KURATUKURI $^{1}$, \\ TOMOAKI TANAKA ${ }^{1}$, YUTAKA KAWAHITO ${ }^{2}$, HAJIME SANO ${ }^{4}$, NORIO YOSHIMURA ${ }^{3}$, \\ TATSUYA NAKATANI $^{1}$ and RIKIO YOSHIMURA ${ }^{1}$ \\ ${ }^{1}$ Department of Urology, Osaka City University Graduate School of Medicine, Osaka 545-8585; \\ Departments of ${ }^{2}$ Inflammation and Immunology, and ${ }^{3}$ Transplantation and Regenerative Surgery, \\ Graduate School of Medical Science, Kyoto Prefectural University of Medicine, Kyoto 602-0841; \\ ${ }^{4}$ Department of Internal Medicine, Hyogo College of Medicine, Hyogo 663-8501, Japan
}

Received November 26, 2009; Accepted December 28, 2009

DOI: $10.3892 / \mathrm{mmr} 00000261$

\begin{abstract}
Recent studies have demonstrated that the cysteinylleukotriene $_{1}$ receptor $\left(\mathrm{CysLT}_{1} \mathrm{R}\right)$ antagonist induces the growth arrest of cancer cells through apoptosis. In this study, we examined the effects of the CysLT $_{1} \mathrm{R}$ antagonist on cell proliferation in urological cancer cell lines, including renal cell carcinoma, bladder cancer, prostate cancer and testicular cancer cells. The inhibitory effect of the $\mathrm{CysLT}_{1} \mathrm{R}$ antagonist on the urological cancer cells was investigated using the MTT assay and flow cytometry. The CysLT $\mathrm{T}_{1} \mathrm{R}$ antagonist induced a reduction in cell viability with a half-maximal concentration of growth inhibition in all the urological cancer cell lines, and arrested the growth of the cells through early apoptosis. In conclusion, the $\mathrm{CysLT}_{1} \mathrm{R}$ antagonist may mediate potent antiproliferative effects against urological cancer cells through early apoptosis, and may therefore serve as a novel therapeutic target in the treatment of urological cancer.
\end{abstract}

\section{Introduction}

Angiogenetic factors play important roles in urological as well as in other types of cancer. In recent years, the expression of angiogenic factors in solid human tumors has been widely reported (1). Growth factors secreted by tumor cells such as fibroblast growth factor and transforming growth factor have been found to increase neovascularization in vivo and in vitro (2).

The metabolism of arachidonic acid (AA) by the cyclooxygenase (COX) or the lipoxygenase (LOX) pathway generates eicosanoids, which have been implicated in the pathogenesis

Correspondence to: Dr Rikio Yoshimura, Department of Urology, Osaka City University Hospital, 1-4-3 Asahi-machi, Abeno-ku, Osaka 545-8585, Japan

E-mail: jasmin@med.osaka-cu.ac.jp

Key words: cysteinyl-leukotriene ${ }_{1}$ receptor antagonist, urological cancer cells, apoptosis of a variety of human diseases, including cancer, where they are significantly involved in tumor promotion, progression and metastasis.

Leukotriene (LT) belongs to an important group of pro-inflammatory mediators and is synthesized by AA via the 5-LOX pathway. The activity of 5-LOX leads to the formation of unstable $\mathrm{LTA}_{4}$, which can be converted into $\mathrm{LTB}_{4}$ or cysteinyl (Cys)LTs $\left(\mathrm{LTC}_{4}, \mathrm{LTD}_{4}\right.$ and $\left.\mathrm{LTE}_{4}\right)$. $\mathrm{LTD}_{4}$ is the most important component of CysLTs $\left(\mathrm{CysLT}_{1}\right.$ and $\left.\mathrm{CysLT}_{2}\right)$, and the CysLT $_{1}$ receptor $\left(\mathrm{CysLT}_{1} \mathrm{R}\right)$ is specific for $\mathrm{LTD}_{4}(3)$. Generally, CysLTs are important mediators of human bronchial asthma, and many CysLT receptor antagonists are clinically used in its treatment.

We previously demonstrated that the 5-LOX inhibitor prevents urological cancer cell growth through apoptosis (4). However, few reports have addressed the relationship between $\mathrm{CysLT}_{1} \mathrm{R}$ and carcinogenesis, and fewer still have provided evidence suggesting that the $\mathrm{CysLT}_{1} \mathrm{R}$ antagonist induces the growth arrest of cancer cells through apoptosis.

With this background, the present study aimed to examine the inhibitory effect of the $\mathrm{CysLT}_{1} \mathrm{R}$ antagonist in renal cell carcinoma (RCC), bladder cancer (BC), prostate cancer (PC) and testicular cancer (TC) cell lines.

\section{Materials and methods}

Reagents and materials. RPMI-1640 was purchased from Nissui Pharmaceutical Co. (Tokyo, Japan). Fetal bovine serum (FBS) and a penicillin-streptomycin mixture were from BioWhittaker (Walkersville, MD, USA). Trypsin/EDTA was from Gibco BRL (Rockville, MD, USA). Montelukast is a selective and orally active $\mathrm{CysLT}_{1} \mathrm{R}$ antagonist (LKT Laboratories, Inc., MN, USA) with demonstrated effectiveness for treating allergic asthma and allergic rhinitis in adults as well as in children as young as 12 months of age for allergic asthma and 6 months of age for allergic rhinitis (5).

Cell cultures. The human RCC cell line (Caki-1), human $\mathrm{BC}$ cell line (T24), human PC cell lines ( $\mathrm{LNCaP}, \mathrm{PC} 3$ and 
Table I. Effect of the CysLT 1 R antagonist on the viability of human urological cancer cells as determined by the MTT assay.

\begin{tabular}{|c|c|c|c|c|}
\hline $\mathrm{CysLT}_{1} \mathrm{R}$ antagonist & $12.5 \mu \mathrm{M}(\%)$ & $25 \mu \mathrm{M}(\%)$ & $50 \mu \mathrm{M}(\%)$ & $100 \mu \mathrm{M}(\%)$ \\
\hline \multicolumn{5}{|l|}{ RCC cell line } \\
\hline Caki-1 & 107.2 & 116.8 & 122.4 & 15.6 \\
\hline \multicolumn{5}{|l|}{$\mathrm{BC}$ cell line } \\
\hline $\mathrm{T} 24$ & 101.3 & 102.6 & 81.2 & 18.0 \\
\hline \multicolumn{5}{|l|}{ PC cell lines } \\
\hline PC3 & 103.2 & 98.9 & 102.6 & 18.9 \\
\hline DU-145 & 116.5 & 43.6 & 19.8 & 12.4 \\
\hline $\mathrm{LNCaP}$ & 101.0 & 101.8 & 23.4 & 11.8 \\
\hline \multicolumn{5}{|l|}{ TC cell line } \\
\hline NEC-8 & 108.4 & 115.4 & 121.2 & 21.8 \\
\hline
\end{tabular}

Concentration-response analysis of the viability of human urological cancer cells treated with the CysLT ${ }_{1} \mathrm{R}$ antagonist (12.5-100 $\left.\mu \mathrm{M}\right)$, carried out using the MTT assay. Data are expressed as the percentage of control culture conditions.

DU-145) and human TC cell line (NEC-8) were obtained from the Health Science Research Resources Bank (HSRRB, Osaka, Japan). Cells were grown in a culture flask (Nunc, Roskilde, Denmark) in RPMI-1640 supplemented with $10 \% \mathrm{FBS}, 100 \mathrm{U} / \mathrm{ml}$ penicillin and $100 \mu \mathrm{g} / \mathrm{ml}$ streptomycin in a humidified $5 \% \mathrm{CO}_{2}$ atmosphere at $37^{\circ} \mathrm{C}$. The media were changed every 3 days, and cells were separated via trypsinization using trypsin/EDTA upon reaching subconfluence.

Cell-proliferation studies. Approximately $1.0 \times 10^{4}$ cells placed on $8 \times 8-m m$ diameter multichamber slides (Nunc, Copenhagen, Denmark) were treated with the $\mathrm{CysLT}_{1} \mathrm{R}$ antagonist dissolved in ethanol. The final concentration of ethanol was $<0.05 \%$. Cell viability was measured at day 1 using a microplate reader with a modified 3-[4,5-dimethylthiazol-2-thiazolyl]2,5-diphenyltetrazolium bromide (MTT) assay (WST-1 assay; Dojindo, Kumamoto, Japan) and presented as the percentage of control culture conditions.

Flow cytometry

Annexin $V$ and propidium iodide staining. The effect of the $\operatorname{CysLT}_{1} \mathrm{R}$ antagonist on urological cancer cells was determined by dual staining with Annexin V-FITC and propidium iodide (PI) using the Annexin V-FITC Apoptosis Detection kit I (Biosiences Pharmingen). Annexin V-FITC and PI were added to the cellular suspension as specified in the manufacturer's instructions, and a sample fluorescence of $1.0 \times 10^{4}$ cells was analyzed by flow cytometry, carried out with FACScan (Becton Dickinson, Germany). Cells that were Annexin V-FITC-positive and PI-negative were identified as early apoptotic. Cells that were Annexin V-FITC-positive and PI-positive were identified as late apoptotic or necrotic.

Identification of DNA fragmentation. The assay was performed using the TdT-mediated dUTP Nick End Labelling (TUNEL) method using the Apo-Direct ${ }^{\mathrm{TM}}$ kit (Becton Dickinson). Following the experiments, urological cancer cells in suspension $\left(1 \times 10^{6} / \mathrm{ml}\right)$ were fixed with $1 \%$ PBS, washed in PBS and suspended in $70 \%(\mathrm{v} / \mathrm{v})$ ice-cold ethanol, then stored at $-20^{\circ} \mathrm{C}$ until use. The positive and negative controls and the sample were stained with FITC-dUTP by incubation in terminal deoxynucleotidyl transferase buffer as specified in the manufacturer's instructions, and the sample fluorescence of $1.0 \times 10^{4}$ cells was analyzed using flow cytometry (Becton Dickinson). Results are expressed as the percentage of TUNEL-positive cells.

\section{Results}

Cys $L T_{1} R$ antagonist-induced growth inhibition in urological cancer cells. To investigate the effects of the CysLT ${ }_{1} \mathrm{R}$ antagonist on urological cancer cell proliferation, cell viability was analysed in vitro using a modified MTT assay. The CysLT $\mathrm{C}_{1} \mathrm{R}$ antagonist induced a reduction in cell viability at the halfmaximal concentration of growth inhibition of urological cancer cells in the range of $12.5-100 \mu \mathrm{M}$, and arrested the growth of all the urological cancer cell lines (Table I).

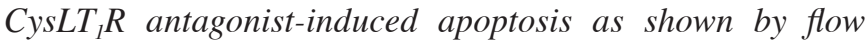
cytometry. The effects of the $\mathrm{CysLT}_{1} \mathrm{R}$ antagonist on the apoptosis of the urological cancer cells compared with the controls are shown in Fig. 1. Upon treatment with $100 \mu \mathrm{M}$ $\mathrm{CysLT}_{1} \mathrm{R}$ antagonist, nearly all the urological cancer cells underwent early but not late apoptosis (Fig. 1). CysLT $R$ antagonist $(100 \mu \mathrm{M})$ induced DNA fragmentation in the urological cancer cells (Fig. 2).

\section{Discussion}

Leukotrienes (LTs) are biologically active fatty acids derived from the oxidative metabolism of arachidonic acid (AA) $(6,7)$ via the 5-LOX pathway. The activity of 5-LOX leads to the formation of unstable $\mathrm{LTA}_{4}$, which is converted into either $\mathrm{LTB}_{4}$ or CysLTs $\left(\mathrm{LTC}_{4}, \mathrm{LTD}_{4}\right.$ and $\left.\mathrm{LTE}_{4}\right)$. CysLTs are components of a slow-reacting substance of anaphylaxis. $\mathrm{LTD}_{4}$ plays the most important role in CysLTs $\left(\mathrm{CysLT}_{1}\right.$ and $\left.\mathrm{CysLT}_{2}\right)$, and CysLT $_{1}$ is specific for $\mathrm{LTD}_{4}$. LTs are potent biochemical mediators released from mast cells, eosinophils and basophils 
Caki-1
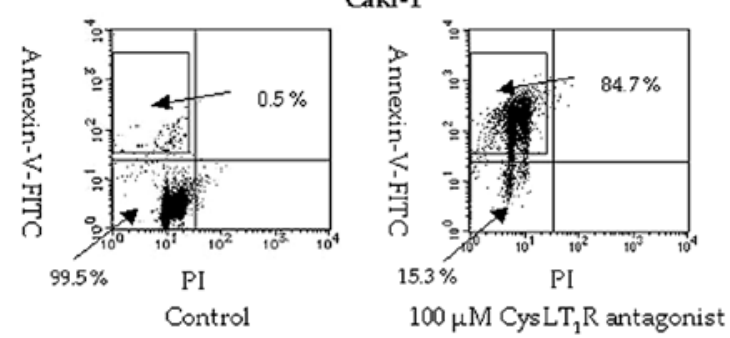

PC3
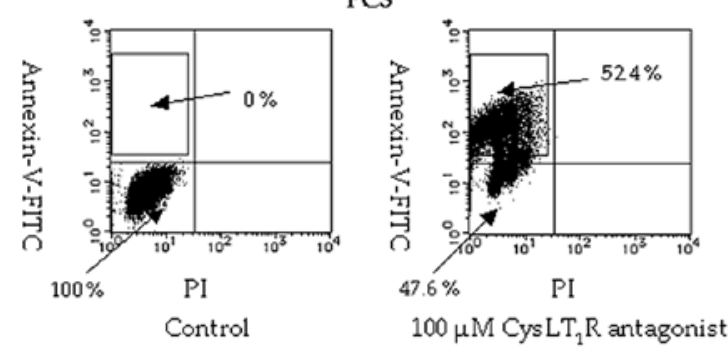

LNCaP

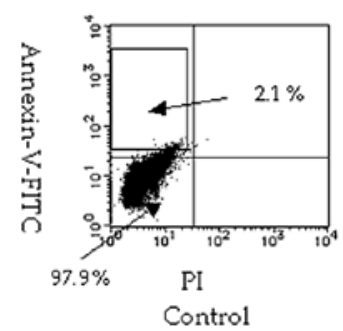

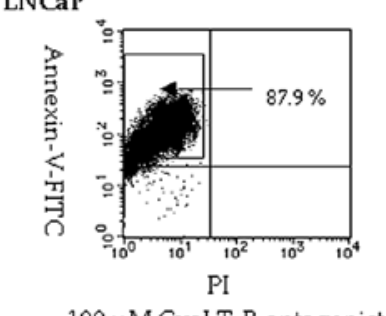

$100 \mu \mathrm{M}$ Cys LT $_{1} \mathrm{R}$ antagonist

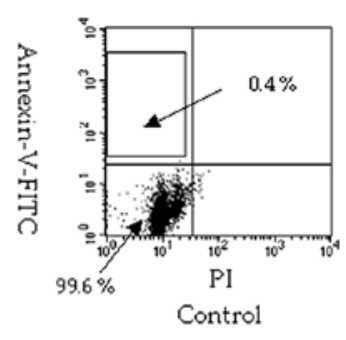

T24

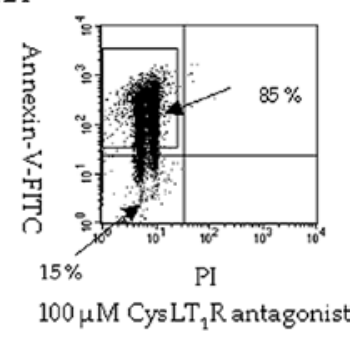

DU-145
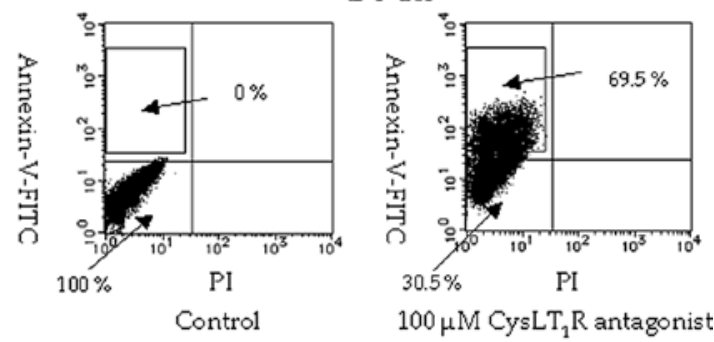

NEC-8
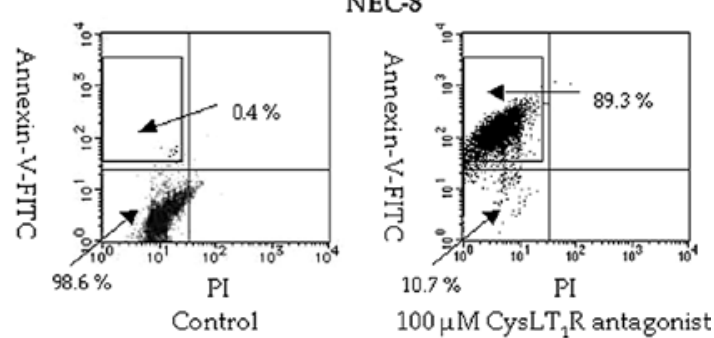

Figure 1. Effects of the CysLT $R$ R antagonist on apoptosis by flow cytometry. Nearly all the urological cancer cells upon treatment with $100 \mu \mathrm{M}$ CysLT $\mathrm{R}_{1}$ antagonist underwent early apoptosis. FITC-Annexin V/PI flow cytometry diagrams of a representative experiment are shown.
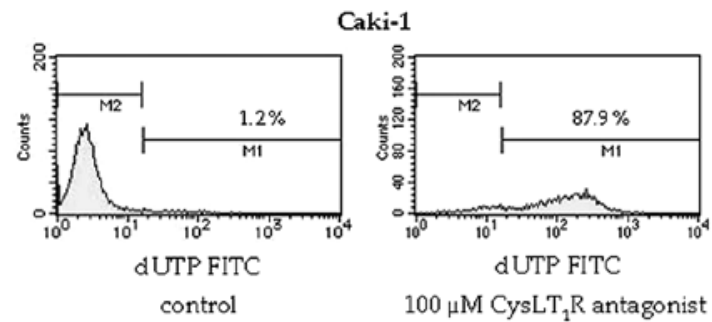

PC3
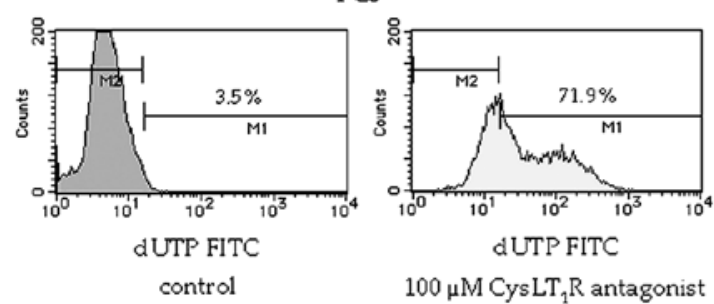

LNCaP

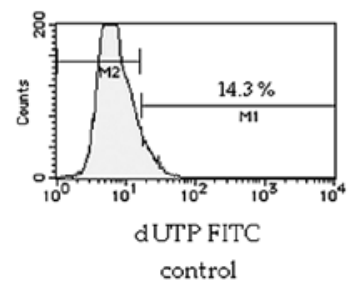

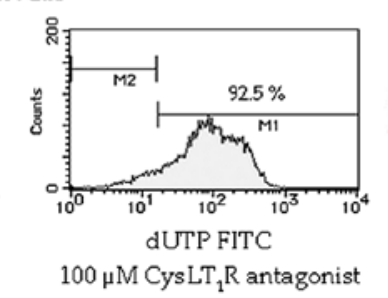
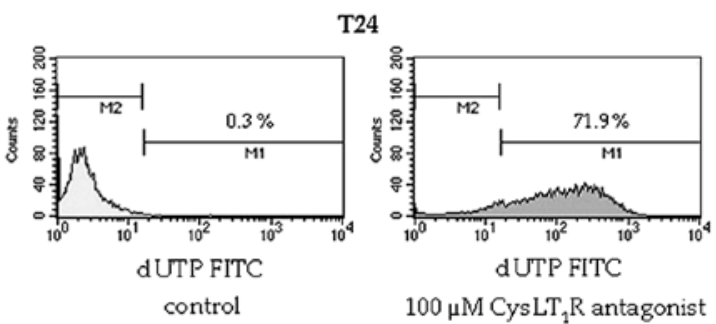

DU-145
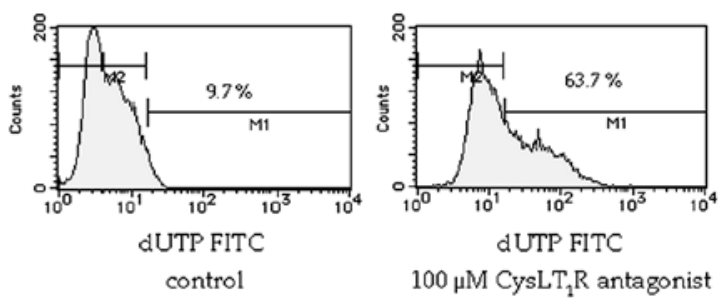

NEC-8

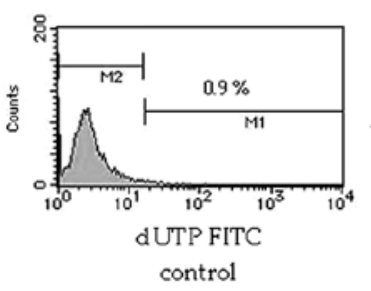

Figure 2. Effects of the CysLT $\mathrm{R}_{1} \mathrm{R}$ antagonist on DNA fragmentation by flow cytometry. The CysLT $\mathrm{R}_{1}$ antagonist (100 $\left.\mu \mathrm{M}\right)$ induced DNA fragmentation in the urological cancer cell lines. Typical flow cytometry histograms of a representative experiment are shown. 
that work to contract airway smooth muscle, increase vascular permeability, increase mucus secretions and to attract and activate inflammatory cells in the airways of patients with asthma (8). The action of LTs can be blocked through one of two specific mechanisms: i) the inhibition of LT production, or ii) the antagonism of LT binding to cellular receptors.

The 5-LOX inhibitor inhibits LT formation (especially $\mathrm{LTB}_{4}, \mathrm{LTC}_{4}, \mathrm{LTD}_{4}$ and $\mathrm{LTE}_{4}$ ). In our previous study, the 5-LOX inhibitor attenuated the growth of human urological cancer and induced apoptosis through the AA pathway (4). With this background, we examined whether or not the CysLT $_{1} \mathrm{R}$ antagonist prevents urological cancer cell growth.

In the present study, we demonstrated using an MTT assay that co-incubation of urological cancer cells with the CysLT $\mathrm{R}_{1} \mathrm{R}$ antagonist halted the growth of urological cancer cells, and potently inhibited cell growth in a dose-dependent manner. The results indicated that CysLT $_{1} R$ is essential for the cell growth of urological cancer cells. However, the mechanism by which the CysLT $_{1} R$ antagonist induced growth inhibition in urological cancer cells required further clarification. To address this problem, we examined whether or not apoptosis was involved in growth suppression in these cancer cell lines. The $\mathrm{CysLT}_{1} \mathrm{R}$ antagonist $(100 \mu \mathrm{M})$ strongly induced early apoptosis in urological cancer cells as determined by flow cytometry, suggesting that apoptosis may be one of the mechanisms through which the $\mathrm{CysLT}_{1} \mathrm{R}$ antagonist prevents urological cancer cell growth. This provides the first indication that, through early apoptosis, the $\mathrm{CysLT}_{1} \mathrm{R}$ antagonist inhibits urological cancer cell growth.

Regarding $\mathrm{CysLT}_{1} \mathrm{R}$ and colon cancer, Ohd et al found that $\mathrm{CysLT}_{1} \mathrm{R}$ was overexpressed in human colorectal cancer, and was significantly correlated with COX-2 and 5-LOX. They demonstrated that the expression of $\mathrm{CysLT}_{1} \mathrm{R}$ was higher in high-grade and early-stage carcinoma, suggesting typical differences in colon cancer (9). Furthermore, survival time was found to be slightly shorter in patients with highintensity CysLT $_{1} \mathrm{R}$ staining than in those with low-intensity staining (10). In addition, we previously found that CysLT $_{1} R$ was overexpressed in human PC and RCC, and that the expression of $\mathrm{CysLT}_{1} \mathrm{R}$ was higher in high- than in low-grade cancer $(11,12)$. Together, these reports suggest that there is a relationship between $\mathrm{CysLT}_{1} \mathrm{R}$ and various cancers, and that the $\mathrm{CysLT}_{1} \mathrm{R}$ antagonist can prevent cell growth in other types of cancer besides urological cancer.
In conclusion, our study provides evidence that the mechanisms of the cell growth and apoptosis of urological cancer cells involve CysLT $_{1} \mathrm{R}$. Growth inhibition of urological cancer cells by blocking $\operatorname{CysLT}_{1} \mathrm{R}$ is associated with the induction of apoptosis. Thus, the $\mathrm{CysLT}_{1} \mathrm{R}$ antagonist may serve as a novel target for anti-cancer therapies.

\section{References}

1. Weidner N, Folkman J, Pozza F, Bevilaqua P, Allred EN and Moore DH: Tumor angiogenesis: a new significant and independent prognostic indicator in early stage breast carcinoma. J Natl Cancer Inst 84: 1875-1887, 1992.

2. Lafyatis R, Thompson NL, Remmers EF, Flanders KC, Roche NS and Kim SJ: Transforming growth factor-beta production by synovial tissues from rheumatoid patients and streptococcal cell wall arthritic rats. Studies on secretion by synovial fibroblastlike cells and immunohistologic localization. J Immunol 143: 1142-1148, 1989.

3. Lynch KR, O'Neill GP, Liu Q, et al: Characterization of human cysteinyl leukotriene $\mathrm{CysLT}_{1}$ receptor. Nature 399: 789-793, 1999.

4. Matsuyama M, Yoshimura R, Tsuchida K, Takemoto Y, Segawa Y, Shinnka T, Kawahito Y, Sano H and Nakatani T: Lipoxygenase inhibitors prevent urological cancer cell growth. Int J Mol Med 13: 665-668, 2004.

5. Storms W: Update on montelukast and its role in the treatment of asthma, allergic rhinitis and exercise-induced bronchoconstriction. Expert Opin Pharmacother 8: 2173-2187, 2007.

6. Horwitz RJ, McGill KA and Busse WW: The role of leukotriene modifiers in the treatment of asthma. Am J Respir Crit Care Med 157: 1363-1371, 1998.

7. Wenzel SE: New approaches to anti-inflammatory therapy for asthma. Am J Med 104: 287-300, 1998.

8. Drazen J: Clinical pharmacology of leukotriene receptor antagonists and 5-lipoxygenase inhibitors. Am J Respir Crit Care Med 157: 233-237, 1998.

9. Ohd JF, Wikstrom K and Sjolander A: Leukotrienes induce cellsurvival signaling in intestinal epithelial cells. Gastroenterology 119: 1007-1018, 2000.

10. Nielsen CK, Campbell JI, Ohd JF, et al: A novel localization of the G-protein-coupled CysLT 1 receptor in the nucleus of colorectal adenocarcinoma cells. Cancer Res 65: 732-742, 2005.

11. Matsuyama M, Hayama T, Funao K, et al: Overexpression of cysteinylLT ${ }_{1}$ receptor in prostate cancer and CysLT $_{1} \mathrm{R}_{\text {antagonist }}$ inhibits prostate cancer cell growth through apoptosis. Oncol Rep 18: 99-104, 2007.

12. Funao K, Matsuyama M, Naganuma T, et al: The cysteinylLT receptor in human renal cell carcinoma. Mol Med Rep 1: 185-189, 2008. 